\title{
Kinetics of drying Bactris gasipaes Kunth sub-products: comparison of mathematical models
}

Cinética de secado de subproductos del Bactris gasipaes Kunth: una comparación de modelos matemáticos

Cinética secando subprodutos de Bactris gasipaes Kunth: uma comparação de modelos matemáticos

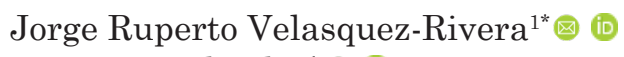

Jesus R. Melendez ${ }^{1}$ 잉 (D)

Manuel G. Roca-Argüelles ${ }^{2}$ (a) (i)

José L. Rodríguez-Sánchez ${ }^{3}$;: (i)

Rev. Fac. Agron. (LUZ). 2022, 39(1): e223901

ISSN 2477-9407

DOI: https://doi.org/10.47280/RevFacAgron(LUZ).v39.n1.01

Food Technology

Associate editor: Dra. Gretty Ettiene
${ }^{1}$ Universidad Católica de Santiago de Guayaquil, Facultad de Educación Técnica para el Desarrollo, Carrera de Ingeniería Agroindustrial, C.P. 090615, Guayaquil, Ecuador

${ }^{2}$ Instituto de Farmacia y Alimentos-Universidad de La Habana. C.P. 17100 , Cuba.

${ }^{3}$ Instituto de Investigaciones para la Industria Alimenticia-Cuba, La Habana. C.P. 17100, Cuba

Received: 01-02-2020

Accepted: 10-07-2021

Published: 16-12-2021
Keywords:

Kinetics of drying

Chopped

Crushed

Mathematical model

Waste

\begin{abstract}
The industrialization of the heart of palm (palm heart), obtained from the sprout of a palm known as pejibaye, chontaduro, or peach palm (Bactris gasipaes Kunth), generates two main products: the fruit and the heart of the stem. The stem produces a highly perishable residue due to its high humidity, making drying an alternative to increase its useful life. The main objective of this study was to describe which of the selected mathematical models conform to better drying kinetics in samples (by-product) of palm heart (palm heart), according to the selected statistical criteria. Mathematical Modeling of the by-product drying curves (the heart of palm) was performed at two working temperatures (70 and 80 ${ }^{\circ} \mathrm{C}$ ) and two groups, one minced and the other ground. The results of the water content were statistically processed to find the most convenient model among those proposed by other researchers. The calculation of the parameters of the different drying models was carried out with the STATISTICA version 8.0 program, using the non-linear estimation tool, according to the quasi-Newton algorithm estimation method. The results show that the models MR $=\exp \left(-k \cdot t^{n}\right)$ and MR $=\exp \left(-(k \cdot t)^{n}\right)$, called Page and modified Page respectively, were the best fit to the experimental data in all cases. Therefore, the models named Page and modified Page best fit the innovative information and the most suitable model.
\end{abstract}




\section{2-7 | Rev. Fac. Agron. (LUZ). 2022, 39(1): e223901. January-March. ISSN 2477-9407.}

\section{Resumen}

La industrialización del palmito (corazón de palma), obtenido del brote de una palma conocida como pejibaye, chontaduro o palma de melocotón (Bactris gasipaes Kunth), genera dos productos principales: la fruta y el corazón del tallo. El tallo genera un residuo que por su alta humedad es muy perecedero, por lo que el secado es una alternativa para aumentar su vida útil. El objetivo principal de este estudio fue describir cuál de los modelos matemáticos seleccionados se ajusta a una mejor cinética de secado en muestras (subproducto) de palmito (corazón de palma), de acuerdo con los criterios estadísticos seleccionados. El modelado matemático de las curvas de secado del subproducto (palmito) se realizó a dos temperaturas de trabajo $\left(70\right.$ y $\left.80^{\circ} \mathrm{C}\right)$ y en dos grupos, uno troceado y el otro triturado. Los resultados del contenido de agua se procesaron estadísticamente para encontrar el modelo más conveniente entre los propuestos por otros investigadores. El cálculo de los parámetros de los diferentes modelos de secado se realizó con el programa STATISTICA versión 8.0, utilizando la herramienta de estimación no lineal, de acuerdo con el método de estimación del algoritmo cuasi-Newton. Los resultados muestran que los modelos MR $=\exp \left(-k \cdot t^{n}\right)$ y $M R=\exp \left(-(k \cdot t)^{n}\right)$, denominados Page and modified Page respectivamente, fueron los de mejor ajuste a los datos experimentales en todos los casos. Los modelos nombrados como Page y modified Page, son los que mejor se ajustaron a la información experimental y al modelo más adecuado.

Palabras clave: cinética de secado, picado, triturado, modelo matemático, residuos

\section{Resumo}

A industrialização do palmito (coração de palma), obtido a partir de um broto de uma palma conhecida como Pejibaye, chontaduro ou palma de pêssego (Bactris gasipaes Kunth), gera dois produtos principais: a fruta e o coração do caule. O caule gera um resíduo que por sua alta umidade é muito perecível, pelo que a secagem é uma alternativa para aumentar sua vida útil. O objetivo principal deste estudo foi descrever qual dos modelos matemáticos selecionados corresponde a uma melhor cinética de secagem em amostras (subproduto) de palmito (coração de palma), de acordo com os critérios estatísticos selecionados. $\mathrm{O}$ modelamento matemático das curvas de secagem do subproduto (palmito) foi realizado a duas temperaturas de trabalho $\left(70\right.$ e $\left.80^{\circ} \mathrm{C}\right)$ e em dois grupos, um picado e o outro triturado. Os resultados do teor de água foram estatisticamente processados para encontrar o modelo mais conveniente entre os propostos por outros pesquisadores. O cálculo dos parâmetros dos diferentes modelos de secagem foi realizado com o programa STATISTICA versão 8.0, utilizando a ferramenta de estimativa não linear, de acordo com o método de estimativa do algoritmo quase-Newton. Os resultados mostram que os modelos $\mathrm{MR}=\exp \left(-\mathrm{k} \cdot \mathrm{t}^{\mathrm{n}}\right)$ e $\mathrm{MR}=\exp \left(-(\mathrm{k} \cdot \mathrm{t})^{\mathrm{n}}\right)$, denominados Page and modified Page respectivamente, foram os de melhor ajuste aos dados experimentais em todos os casos.
Os modelos nomeados como Page and Modified Page são os que melhor se ajustaram à informação experimental e ao modelo mais adequado.

Palavras-chave: cinética secando, picado, moído, modelo matemático, residuos

\section{Introduction}

The generation and bad disposition of by-products of agricultural and agro-industrial activities cause damage to the environment, however, these by-products can contain compounds of high economic value that nowadays are little used (Santacruz et al., 2020). Palmito is a domesticated palm commercially crucial for producing fruits and hearts of palm (Padilha et al., 2021). The industrialization of palmito (heart-of-palm) obtained from the head of a palm known as pejibaye, chontaduro, or peach palm (Bactris gasipaes), is an essential crop in the Amazon (Schroth et al., 2002). The palmito generates two main products: the fruit and the heart of the stem, which have various applications in the agroindustry.

In an industrial context, the use of waste materials from specific food manufacturing processes and other derivatives represents new alternatives for producing products with high nutritional value and environmentally sustainable biofuels. There are alternatives for waste materials with a large amount of lignocellulosic content, such as sugar cane, fruit peels, hearts of palm, which are within this group (Melendez et al., 2021). The production and consumption of palm hearts, especially from the Bactris gasipaes Kunth, generate many lignocellulosic by-products (Vieira et al., 2021). Palm sub-products can be found in flours, rich in dietary fiber (62-71\%), which can be used in other mixing processes and ingredients in food technologies (Bolanho et $a l ., 2015)$. Other specific applications in different research fields related to the use of fibers in the microbiota of the human intestine (Cantu-Jungles et al., 2017) have been studied to improve health and prepare functional foods (Waldron et al., 2003). The large amount of residues generated by the peach palm agroindustry and its cellulose content (34 g.100 g ${ }^{-1}$ ) (Franco et al., 2019) had motivated different studies. In addition, official data show that the heart of palm generates approximately $478,751.39 \mathrm{t}$ of waste per year (Instituto Nacional de Preinversión, 2014), which could be used in other applications. The residue obtained has a high content of dietary fiber; however, due to its high humidity, it is a highly perishable product and, therefore, studies on extending its shelf life are reasonably necessary (Ribeiro et al., 2021), so drying is an alternative to increase its useful life.

Drying is one of the widely used methods of grain, fruit, and vegetable preservation. The critical aim of drying is to reduce the moisture content and increase the lifetime of products by limiting enzymatic and oxidative degradation. In addition, reducing the amount of water, drying reduces crop losses, improves the quality of dried products, and facilitates its transportation, handling, and storage requirements. Drying is a process comprising simultaneous 
heat and mass transfer within the material and between the surface of the material and the surrounding media (Ertekin \& Firat, 2017).

Generally, the temperatures used for drying some agricultural products are between 40 to $60{ }^{\circ} \mathrm{C}$. However, some researchers have used high temperatures $(70,80$, and $90{ }^{\circ} \mathrm{C}$ ), and they do not report extreme changes in physicals and chemicals characteristics (Rojas-Garbanzo et al., 2012; Helm et al., 2014; Rajoriya et al., 2021; Ayetigbo et al., 2021).

The flours obtained from palmito by-products show high values for the total dietary fiber, 59.1 to $65.5 \mathrm{~g} 100 \mathrm{~g}^{-1}$, almost entirely represented by the insoluble fiber, as well as a low proportion of calories 96.1 to $101.1 \mathrm{kcal}$ or $408.2-429.5 \mathrm{~kJ}$ per $100 \mathrm{~g}$ of product when compared to wheat bran. These results highlight this type of flour as a potential source of fiber for human nutrition, particularly as a fibrous ingredient of formulated food and functional supplements (Helm et al., 2014). Furthermore, Vieira et al. (2021) report the obtainment of xylooligosaccharides (XOS) from xylans extracted from these residues, which could be applied as natural antioxidants in functional food and pharmaceutical preparations. However, although these wastes contain substances with high fiber and protein content, which may be of interest in the food industry, the main destinations are landfills, which represent major environmental problems worldwide, related to the affectation to the water bodies, production of high $\mathrm{CO}_{2}$ contents, for which the fertility of the soils should be protected as a fundamental objective of sustainable development (Mendoza et al., 2020a). The recovery of this waste has become one of the most critical challenges in the food industry since it not only allows them to be used again as raw material but also allows lower costs and helps reduce environmental impact (Rezzadori et al., 2012) and sometimes the composition of the soil exerted by the presence of available minerals, which allows better crops (Mendoza et al., 2020b).

In this scenario, research in the Agroindustrial sector has developed unit drying processes to evaluate organic raw materials' behavior when experimenting with different temperatures. Currently, mathematical models allow us to know which models are more efficient (Omolola et al., 2019). In this sense, the determination of the ideal time and temperature are goals of the current industry to lower costs and obtain adequate physical, chemical, rheological, microbiological, and sensory parameters.

Many models have been used to describe the drying process for different agricultural products. These models are used to estimate the drying time of several products under different drying conditions, and how to increase the drying process efficiency, and also to generalize drying curves for the design and operation of dryers. Several investigators have proposed numerous mathematical models for the thinlayer drying of many agricultural products (Ertekin \& Firat, 2017). Nowadays, mathematical simulation and Modeling of drying curves are valuable instruments in order to improve control systems for final product quality under various conditions. These approaches are usually applied to study the factors present in the process, optimize the conditions and working factors, and predict the drying kinetics of products (Mokhtarian et al., 2021).
There are mathematical models such as the one proposed in Page's equation, which is one of the empirical equations that allow us to describe water migration through food drying processes (Simpson et al., 2017). Other authors have worked with some models such as Newton, Modified Page, Henderson \& Pabis, Wang \& Singh, Logarithmic, and others in some agricultural products (Sadaka, 2020; Zhao et al., 2014; Taghian-Dinani et al., 2014). Therefore, this research was oriented to selecting the efficient palmito drying model, as an alternative that allows handling, preservation, and utilization of this by-product in the Agroindustrial and industrial sectors. To carry out the experimental process, we consider the quantitative methodological perspective, with innovative design, of the quasi-experimental type and the level of multiple treatments (Hernández et al., 2014).

Finally, the main objective of this article is to describe which of the selected mathematical models was adjusted to better kinetics of drying in palmito (palm hearts) samples, according to the selected statistical criteria.

\section{Materials and methods}

Methodological approach. The research is framed within the quantitative methodological perspective, with experimental design of the quasi-experimental type and the level of multiple treatments (Hernández et al., 2014).

For the drying study, palmito by-products were worked under a factorial design $2 \times 2$. Two types of cutting (chopped and crushed) and two drying temperatures (70 and $80{ }^{\circ} \mathrm{C}$ ) were taken into account in the experiments with three repetitions. Each of the twelve experimental units consisted of $1.46 \mathrm{~kg}$ with a total of $17.52 \mathrm{~kg}$.

The experimental values of the different tests were processed by InfoStat Group (2015), where the variance analysis for differences was applied as statistical techniques, comparing means through Duncan's multi-range test at probability levels $\mathrm{p} \leq 0.05$ for the variable Performance drying (Percentage).

Preparation of material. The samples used for processing are residues of the palmito (heart-of-palm) obtained from the palm (Bactris gasipaes Kunth). Palm heart by-products were purchased from FACUNDO Agroindustrial enterprise (Babahoyo, Ecuador). The drying process and the kinetic comparisons of the by-product started with a treatment of the raw material in one phase. This phase or stage of preparation considered the selected material and subjected it to two preparation processes. The first condition consisted of the chopping of palmito samples, these sub-products were chopped into rings, under the following dimensions, and cylinders of $5 \mathrm{~mm}$ maximum height, a length of $8 \mathrm{~cm}$ and $0.5 \mathrm{~cm}$ wide were formed. The second condition consisted of the grinding of the samples, using an electric disk mill with $8 \mathrm{~mm}$ diameter holes, Torrey brand (made in Mexico).

In both cases, the by-products were weighed and grouped into two groups as sub-products to be used in the drying process under experimental conditions.

Drying experiment: design. The drying was carried out in the Unitary Operations Laboratory of the 
Chemical Faculty of the University of Guayaquil with the collaboration of the Research Institute of the Food Industry of Cuba and the Laboratory of Bromatology of the Faculty of Medicine Catholic University of Santiago de Guayaquil, Ecuador.

The dried was carried out by a tunnel dryer, with an airflow of $8.4 \mathrm{~m}^{3} \cdot \mathrm{h}^{-1}$, constant pressure of $68.95 \mathrm{kPa}$, area of the drying tunnel of $4893 \mathrm{~cm}^{2}$ of surface, to constant temperatures of 70 and $80{ }^{\circ} \mathrm{C}$, until reaching a moisture scales of $0.1 \mathrm{~kg} \cdot \mathrm{kg}^{-1}$ of solid dry. These data correspond to the drying performance and treatment method (chopped and crushed) of the by-products of palmito. The building the curves of dried, the loss of mass was proceeded to register each $10 \mathrm{~min}$, using a scale connected to the dried system. The results were expressed in tables of contents as contain moisture in the dry base, expressed in $\mathrm{kg}$ (mass of water/mass of solid).

Mathematical Modeling of drying curves. The results of the water content on a dry base are statistically processed to find the most convenient model. In this stage, the four mathematical models selected for the calculation of the drying unit operation were compared; the table 1 shows the selected models.

Table 1. Mathematical models to describe drying kinetics.

\begin{tabular}{|c|c|c|}
\hline $\begin{array}{l}\text { Empirical } \\
\text { Expression }\end{array}$ & Name & Reference \\
\hline $\mathrm{MR}=\exp (-\mathrm{k} . \mathrm{t})$ & Newton & $\begin{array}{c}\text { O’Callaghan (1971); Liu \& } \\
\text { Bakker-Arkema (1997); Togrul } \\
\text { (2006). }\end{array}$ \\
\hline $\mathrm{MR}=\exp \left(-\mathrm{k} \cdot \mathrm{t}^{\mathrm{n}}\right)$ & Page & $\begin{array}{c}\text { Agrawal \& Singh (1977); Zhang } \\
\text { \& Litchfield (1991); Sozzi et al. } \\
\text { (2021). }\end{array}$ \\
\hline $\mathrm{MR}=\exp \left[-(\mathrm{k} \cdot \mathrm{t})^{\mathrm{n}}\right]$ & $\begin{array}{l}\text { Modified } \\
\text { Page }\end{array}$ & $\begin{array}{l}\text { Overhults et al. (1973); White et } \\
\text { al. (1981); Sharma et al. (2005). }\end{array}$ \\
\hline $\mathrm{MR}=\mathrm{a}-\exp (-\mathrm{k} \cdot \mathrm{t})$ & $\begin{array}{l}\text { Henderson } \\
\text { \& Pabis }\end{array}$ & $\begin{array}{l}\text { Westerman et al. (1973); Chh- } \\
\text { ninman (1984); Shi et al. (2008). }\end{array}$ \\
\hline
\end{tabular}

MR: Quotient of moisture.

The quotient of moisture, MR, was calculated according to the following expression:

$\mathrm{MR}=\left(\mathrm{X}-\mathrm{X}_{\mathrm{e}}\right) /\left(\mathrm{X}_{\mathrm{o}}-\mathrm{X}_{\mathrm{e}}\right)$

Where $\mathrm{X}$ is the contained of moisture in dry base to a time $t$; $\mathrm{X}_{\mathrm{e}}$ contained moisture in scale in dry base, and $\mathrm{X}_{\mathrm{o}}$ contained initial moisture in dry base.

Statistical criteria for the selection of the mathematical model. According to the method of estimation of the Newton quasi- algorithm, the calculation of the parameters of the different models of dried was made by the STATISTICA 8.0 software (StatSoft Inc., 2007) using the tool Odd number linear assessment. Furthermore, to evaluate the adjustment of the mathematical models with the experimental information was used the following statistical criteria: coefficient of correlation (r), Chi-square test reduced $\left(\mathrm{X}_{\text {red }}^{2}\right)$, and the square root of the residual ones to the square (RRC).

The best adjustments were those models that presented the higher values of $\mathrm{r}$ and the minor of $\left(\mathrm{x}_{\text {red }}^{2}\right)$ and $\mathrm{RRC}$ (Yaldiz \& Ertekin, 2001; Togrul \& Pehlivan, 2002).
The following equations were used to calculate the statistics mentioned before:

$$
\begin{aligned}
\mathrm{x}_{\text {red }}^{2} & =\sum_{\mathrm{i}=1}^{\mathrm{N}} \frac{(\mathrm{MR}(\text { exp,i) }-\mathrm{MR}(\mathrm{pre}, \mathrm{i})}{(\mathrm{N}-\mathrm{n})} \\
\mathrm{RRC} & =\frac{\mathrm{N}}{1}\left[\sum^{\left(\mathrm{MR}_{\text {exp, i }-}-\mathrm{MRpre}, \mathrm{i}^{1 / 2}\right]^{1 / 2}}\right.
\end{aligned}
$$

Where $\mathrm{MR}$ exp, i; is the experimental value of the quotient of dampness in a certain time and $\mathrm{MR}{ }_{\text {pre, I }}$; is the corresponding value predicted by the model. $\mathrm{N}$ and $\mathrm{n}$ are the numbers of observations made and the number of parameters of the model, respectively.

\section{Results and discussion}

Drying performance of Palmito by-products. The percentages of drying yields of palm-heart by-products are shown below, with the highest value of $11.10 \%$ for crushed palm hearts and drying at $80{ }^{\circ} \mathrm{C}$. A linear increase in the yield of the dry palmito by-products was observed for the treatment that used the highest temperature. In this case, the process of crushed formed a mass. The kinetics of the loss of water in the process of dehydration of some food materials was recorded by the loss of water from its surface and the formation of a semipermeable crust during drying, known as surface crusts (Velásquez et al., 2017).

The table 2 shows a higher yield at a higher temperature in the sample with the more exposed surface. This phenomenon occurs to a lesser extent in the by-product with less surface exposure to the drying temperature. This kinetic effect of water preservation occurs in the kernels of the palmito by-product of this experiment.

Effect of the temperature in the process of drying. Changes in the moisture in a dry base of the sub-product of palmito with time during the dried to 70 and $80^{\circ} \mathrm{C}$ appear in the figure 1 and 2, respectively.

The characteristic feature of the curves is its similarity with the typical exponential behavior of the process of the dried materials by way of warm airflow, which is more pronounced by the increase of the temperature (Ertekin \& Yaldiz, 2004).

The table 3 presents the values of the adjustment parameters of the selected models.

Table 2. Performance of drying and grinding of palmito (palm-heart) by-products.

\begin{tabular}{ccc}
\hline Type of cut & $\begin{array}{c}\text { Drying temperature } \\
\left({ }^{\circ} \mathbf{C}\right)\end{array}$ & $\begin{array}{c}\text { Performance drying } \\
(\%)\end{array}$ \\
\hline Chopped & 70 & $9.23^{\mathrm{a}}(0.004)$ \\
Crushed & 70 & $9.91^{\mathrm{b}}(0.04)$ \\
Chopped & 80 & $10.14^{\mathrm{c}}(0.01)$ \\
Crushed & 80 & $11.10^{\mathrm{d}}(0.00)$ \\
\hline
\end{tabular}

Means with a letter, $a, b, c, d$ are not significantly different $(p \leq 0.05)$. 


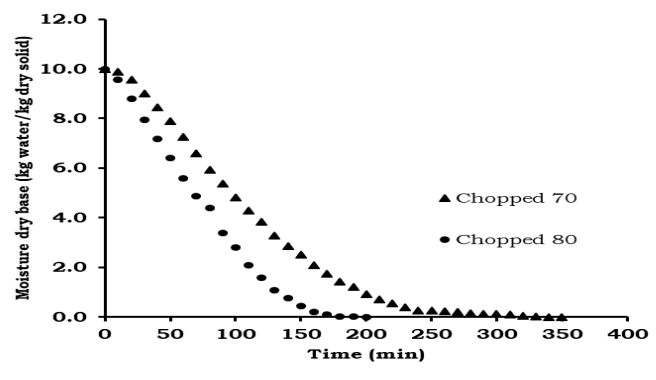

Figure 1. Curves of dried: chopped palmito to $70{ }^{\circ} \mathrm{C}$ $(\Delta)$ and $80^{\circ} \mathrm{C}(\bullet)$.

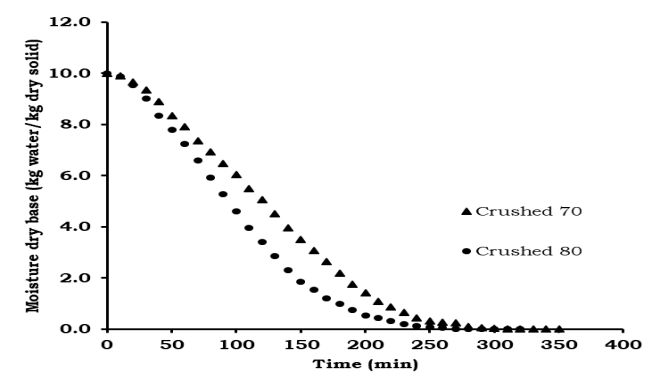

Figure 2. Curves of dried: crushed palmito to $70{ }^{\circ} \mathrm{C}$ $(\Delta)$ and $80^{\circ} \mathrm{C}(\bullet)$.

Table 3. Results of the statistical analysis in the Modeling of the quotient of Moisture vs. the time of dried.

\begin{tabular}{|c|c|c|c|c|}
\hline Material presented- ${ }^{\circ} \mathrm{C}$ & Model & Correlation coefficient (r) & $\mathbf{x}_{\text {red }}^{2}$ & $\mathbf{R R C}^{\mathrm{a}}$ \\
\hline \multirow[t]{4}{*}{ Chopped: $70^{\circ} \mathrm{C}$} & $\mathrm{MR}=\exp (-0,00882-\mathrm{t})$ & 0.968 & 7.34E-03 & 0.0843 \\
\hline & $\mathrm{MR}=\exp \left(-0,000533-\mathrm{t}^{1,576}\right)$ & 0.999 & $1.80 \mathrm{E}-04$ & 0.0130 \\
\hline & $M R=\exp \left(-(0,00834-t)^{1,678}\right)$ & 0.999 & $7.54 \mathrm{E}-05$ & 0.0084 \\
\hline & $\mathrm{MR}=1,1697-\exp (-0,01016-\mathrm{t})$ & 0.982 & $2.12 \mathrm{E}-01$ & 0.4460 \\
\hline \multirow[t]{4}{*}{ Chopped: $80^{\circ} \mathrm{C}$} & $M R=\exp (-0,01224-t)$ & 0.965 & $7.68 \mathrm{E}-03$ & 0.0850 \\
\hline & $\mathrm{MR}=\exp \left(-0,000688-\mathrm{t}^{1,648}\right)$ & 0.997 & $6.59 \mathrm{E}-04$ & 0.0241 \\
\hline & $M R=\exp \left[-(0,01205-t)^{1,641}\right]$ & 0.997 & $6.58 \mathrm{E}-04$ & 0.0241 \\
\hline & $\mathrm{MR}=1,1207-\exp (-0,01376-\mathrm{t})$ & 0.981 & $2.84 \mathrm{E}-01$ & 0.5006 \\
\hline \multirow[t]{4}{*}{ Crushed: $70^{\circ} \mathrm{C}$} & $M R=\exp (-0,00728-t)$ & 0.951 & $1.16 \mathrm{E}-03$ & 0.1060 \\
\hline & $\mathrm{MR}=\exp \left(-0,000388-\mathrm{t}^{1,616}\right)$ & 0.996 & $8.74 \mathrm{E}-04$ & 0.0312 \\
\hline & $M R=\exp \left[-(0,00708-t)^{1,871}\right]$ & 0.998 & $3.89 \mathrm{E}-04$ & 0.0190 \\
\hline & $\mathrm{MR}=1,1788-\exp (-0,00855-\mathrm{t})$ & 0.969 & 3.87E-01 & 0.0984 \\
\hline \multirow[t]{4}{*}{ Crushed: $80^{\circ} \mathrm{C}$} & $M R=\exp (-0,00930-t)$ & 0.960 & $9.41 \mathrm{E}-04$ & 0.0952 \\
\hline & $\mathrm{MR}=\exp \left(-0,000525-\mathrm{t}^{1,576}\right)$ & 0.998 & $4.76 \mathrm{E}-04$ & 0.0209 \\
\hline & $M R=\exp \left[-(0,00889-t)^{1,678}\right]$ & 0.998 & $1.38 \mathrm{E}-04$ & 0.0113 \\
\hline & $\mathrm{MR}=1,1622-\exp (-0,01070-\mathrm{t})$ & 0.974 & 7.88E-03 & 0.0704 \\
\hline
\end{tabular}

\section{a Square root of the residual ones to the square.}

In general, with all models proposed by the quotient of moisture (MR), good results were reached, but the models $\mathrm{MR}=\exp \left(-\mathrm{k} \cdot \mathrm{t}^{\mathrm{n}}\right)$ and MR $=\exp \left[-(\mathrm{k} \cdot \mathrm{t})^{\mathrm{n}}\right]$, named as Page and modified Page respectively, those are which better fit the experimental information data, in all cases, in agreement with the selected statistical criteria. The Page is the best model to describe the drying kinetics in some plant raw materials (Sozzi et al., 2021; Chouaibi et al., 2021). The values of the correlation coefficient were considered, test $\mathrm{X}^{2}$ and the square root of the residual to the square taken as statistical criteria in the selection of the most suitable model.

A graphical representation of the quality of the adjustment of these models appears in the figure 3 that corresponds to the dried to $80{ }^{\circ} \mathrm{C}$ of the sub-product of crushed palmito.

When examining the constant $k$ in the different models shown in table 3 , it appreciates that it is dependent on the temperature. While higher it is, his value goes increasing; from the anomalous diffusion model and also from Fick's model, the correct use of an exponential equation such as Page's equation indicates that the equation will have a possible phenomenological meaning when relevant data at long drying times (Simpson et al., 2017).

Drying kinetics: Presentation of the palmito (heart-of-palm) sample.

Treatments for the sample: chopped vs. crushed. The table 3 shows, when examining the values of the constants $n$ and $k$, the most convenient models are determined: Page and modified Page. In this sense, it was verified that the previous treatment of the by-product of the heart of palm (chopped and crushed) also influences the kinetics of drying because of the constant $n$ of the corresponding model increases or decreases when the treatments were compared: chopped vs. crushed.

According to Karathanos \& Belessiotis (1999), the increase of $n$ was associated with an increase in the thickness of the dry external cape of the product, which affects the speed of 
dried. In this direction, a decrease of the value $k$ was associated when comparing the treatments chopped vs. crushed due to the formation of the outer crust.

The value of the drying rate constant $\mathrm{k}$ decreases with the increase in initial material load, indicating slower drying of the product (Kaleta \& Górnicki, 2010).

All this carries out as a consequence of a decrease in the speed of dried, a phenomenon that was possible to estimate in figures 4 and 5 .

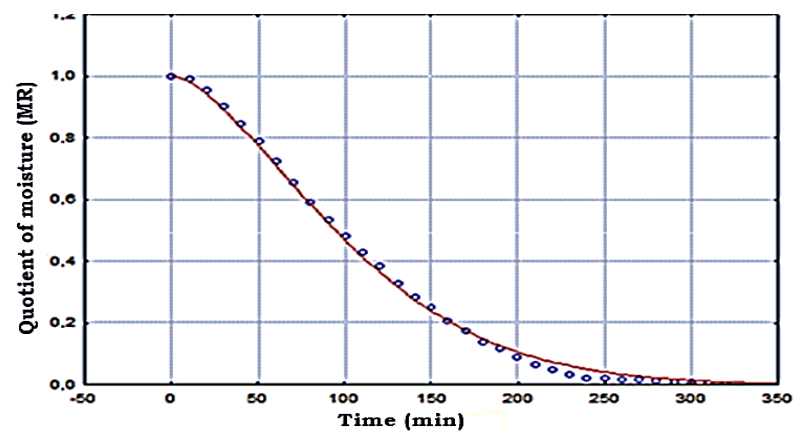

Figure 3. Curves of dried to $80{ }^{\circ} \mathrm{C}$ experimentally (oo) and the predicted one for the Model of Pages modified (line) for the sub-product of crushed palmito.

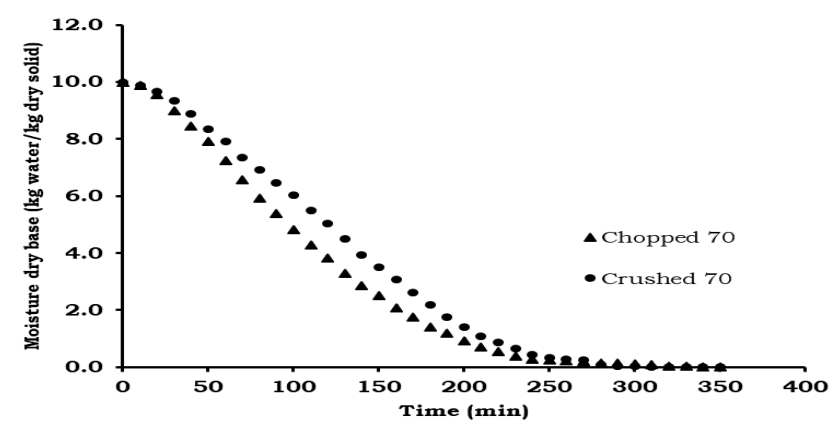

Figure 4. Effect of the previous treatment of the subproducts of palmito in the Kinetic of dried to $70^{\circ} \mathrm{C}$.

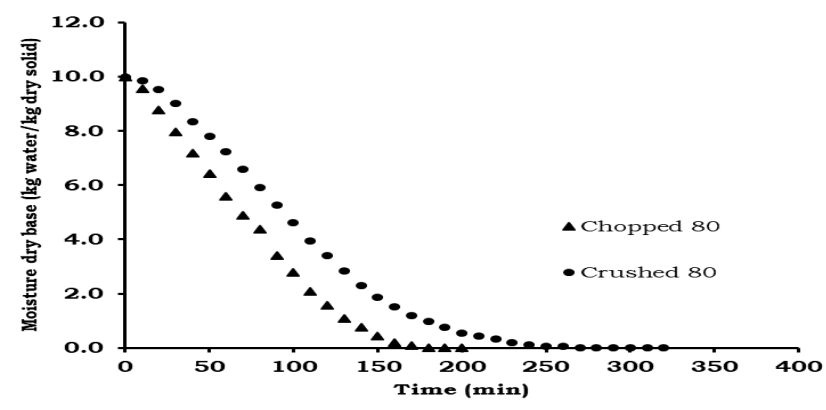

Figure 5. Effect of the previous treatment of the subproducts of palmito in the Kinetic of dried to $80^{\circ} \mathrm{C}$.

\section{Conclusions}

Models named as Page and modified Page respectively, are the ones that better fit the experimental information in all the cases, in agreement with the values of the coefficient of correlation; the test $x^{2}$ and the square root of the residual to the square taken as statistical criteria in the selection of the most suitable model.

\section{Acknowledgment}

A special thanks to the manager to the Unitary Operations Laboratory of the Chemical Faculty of the University of Guayaquil, the Research Institute of the Food Industry of Cuba, and the Laboratory of Bromatology of the Faculty of Medicine of the Catholic University of Santiago de Guayaquil, Ecuador, which allowed a happy ending with this study.

\section{Literature cited}

Agrawal, Y. C. \& Singh, R. P. (1977). Thin layer studies on short grain rough rice. Transactions of the American Society of Agricultural Engineers, 77: 3531. https://doi.org/10.13031/ISSN 0149-9890

Aregbesola, O.A., Ogunsin, B. S., Sofolahan, A. E. \& Chime, N. N. (2015). Mathematical Modeling of thin layer characteristics of dika (Irvingia gobonensis) nuts and kernels. Nigerian Food Journal, 33: 83-89. https://doi.org/10.1016/j.nifoj.2015.04.012

Ayetigbo, O., Latif, S., Abass, A. \& Müller, J. (2021). Drying kinetics and effect of drying conditions on selected physicochemical properties of foam from yellow-fleshed and white-fleshed cassava (Manihot esculenta) varieties. Food and Bioproducts Processing, 127: 454-464. https://doi.org/10.1016/j.fbp.2021.04.005

Baini, R. \&. Langrish, T. A. G. (2007). Choosing an appropriate drying model for intermittent and continuous drying of bananas. Journal of Food Engineering, 79(1), 330-343. https://doi. org/10.1016/j.jfoodeng.2006.01.068

Bolanho, B. C., Danesi, E. D. G. \& Beléia, A. D. P. (2015). Carbohydrate composition of peach palm (Bactris gasipaes Kunth) by-products flours. Carbohydrate Polymers, 124: 196-200. https://doi. org/10.1016/j.carbpol.2015.02.021

Cantu-Jungles, T. M., Cipriani, T. R., Lacomini, M., Hamaker, B.R. \& Cordeiro, L. M. C. (2017). A pectic polysaccharide from peach palm fruits (Bactris gasipaes) and its fermentation profile by the human gut microbiota in vitro. Bioactive Carbohydrates and Dietary Fibre, 9: 1-6. https://doi.org/10.1016/j.bcdf.2016.11.005

Chhninman, M. S. (1984). Evaluation of selected mathematical models for describing thin layer drying of in-shell pecans. Transactions of the American Society of Agricultural Engineers, 27(2), 610615. https://doi.org/10.13031/2013.32837

Chouaibi, M., Snoussi, A., Attouchi, S. \& Ferrari, G. (2021). Influence of drying processes on bioactive compounds profiles, hydroxymethylfurfural, color parameters, and antioxidant activities of Tunisian eggplant (Solanum melongena L.). Journal of Food Processing and Preservation, e15460. https:// doi.org/10.1111/jfpp. 15460

Doymaz, İ. (2005). Drying characteristics and kinetics of okra. Journal of Food Engineering, 69(3), 275-279. https://doi. org/10.1016/j.jfoodeng.2004.08.019

Ertekin, C. \&. Firat, M. Z. (2017). A comprehensive review of thinlayer drying models used in agricultural products. Critical. Reviews in Food Science and Nutrition, 57(4), 701-717. https://doi.org/10.1080/10408398.2014.910493

Ertekin, C. \& Yaldiz, O. (2004). Drying of eggplant and selection of a suitable thin layer drying model. Journal of Food Engineering, 63(3), 349-359. https://doi.org/10.1016/j.jfoodeng.2003.08.007

Franco, T. S., Potulski, D. C., Viana, L. C., Forville, E., de Andrade, A. S. \& Bolson de Muniz, G. I. (2019). Nanocellulose obtained from residues of peach palm extraction (Bactris gasipaes). Carbohydrate Polymers, 218: 8-19. https://doi.org/10.1016/j. carbpol.2019.04.035

Helm, C.V., Raupp, D. S. \& Santos, A. F. (2014). Development of peach palm fibrous flour from the waste generated by the heart of palm agribusiness. Acta Scientiarum. Technology, 36(1), 171-177. https://doi.org/10.4025/actascitechnol. v36i1.17165 
Hernández, R., Fernández, C., Baptista, P., Méndez, S. \& Mendoza, C. (2014). Metodología de la investigación. México, DF: Mcgrawhill.

InfoStat Group. (2015). Versión libre 20151. Córdoba: Universidad Nacional de Córdoba, www.infostat.com.ar

Instituto Nacional de Preinversión. (2014). Atlas Bioenergético de la República del Ecuador. First edition. Quito: Esin-consultora S.A.

Kaleta, A. \& Górnicki, K. (2010). Some remarks on evaluation of drying models of red beet particles. Energy Conversion and Management, 51(12), 2967-2978. https://doi.org/10.1016/j. enconman.2010.06.040

Karathanos, V. T. \& Belessiotis, V. G. (1999). Application of a thinlayer equation to drying data of fresh and semi-dried fruits. Journal of Agricultural Engineering Research, 74(4), 355-361. https://doi.org/10.1006/jaer.1999.0473

Liu, Q. \& Bakker-Arkema, F. W. (1997). Stochastic modelling of grain drying: Part 2. Model development. Journal of Agricultural Engineering Research, 66(4), 275-280. https://doi.org/10.1006/ jaer.1996.0145

Melendez, J. R., Velasquez-Rivera, J., El Salous, A. \& Peñalver, A. (2021). Management for the production of $2 \mathrm{G}$ biofuels: Review of the technological and economic scenario. Revista Venezolana de Gerencia, 26(93), 78-91. https://doi.org/10.37960/rvg. v26i93.34965

Mendoza, B., Béjar, J., Luna, D., Osorio, M., Jimenez, M. \& Melendez, J. R. (2020a). Differences in the ratio of soil microbial biomass carbon (MBC) and soil organic carbon (SOC) at various altitudes of Hyperalic Alisol in the Amazon region of Ecuador. F1000Research, 9. https://doi.org/10.12688/ f1000research.22922.1

Mendoza, B., Guananga, N., Melendez J. R. \& Lowy, D. A. (2020b). Differences in total iron content at various altitudes of amazonian andes soil in Ecuador. F1000Research, 9: 128. https://doi.org/10.12688/f1000research.22411.1

Mokhtarian, M., Majd, M. H., Garmakhany, A. D. \& Zaerzadeh, E. (2021). Predicting the moisture ratio of dried tomato slices using artificial neural network and genetic algorithm Modeling. Journal of Research and Innovation in Food Science and Technology, 9(4), 411-422. https://doi.org/10.22101/ jrifst.2021.258797.1203

O'Callaghan, J. R., Menzies, D. J. \& Bailey, P. H. (1971). Digital simulation of agricultural drier performance. Journal of Agricultural Engineering Research, 16(3), 223-244. https://doi. org/10.1016/S0021-8634(71)80016-1

Omolola, A. O., Kapila, P. F. \& Silungwe, H. M. (2019). Mathematical Modeling of drying characteristics of Jew's mallow (Corchorus olitorius) leaves. Information Processing in Agriculture, 6(1), 109-115. https://doi.org/10.1016/j.inpa.2018.08.003

Overhults, D. D., White, G. M., Hamilton, M. E. \& Ross, I. J. (1973). Drying soybeans with heated air. Transactions of the American Society of Agricultural Engineers, 16, 195-200. https://doi. org/10.13031/2013.37459

Padilha, J. H. D., Steinmacher, D. \& Quoirin, M. (2021). Peach palm plantlet growth in different culture media in a temporary immersion system. Ciência Rural, 51(3). https://doi. org/10.1590/0103-8478cr20190075

Rajoriya, D., Bhavya, M. L. \&. Hebbar, H. U. (2021). Impact of process parameters on drying behaviour, mass transfer, and quality profile of refractance window dried banana puree. LWT-Food Science and Technology, 145: 111330. https://doi.org/10.1016/j. lwt.2021.111330

Rezzadori, K., Benedetti, S. \& Amante, E. R. (2012). Proposals for the residues recovery: Orange waste as raw material for new products. Food and Bioproducts Processing, 90(4), 606-614. https://doi.org/10.1016/j.fbp.2012.06.002

Ribeiro, S. A., Coneglian, R. C. C., Da Silva, B. C., De Deco, T. A., Prudêncio, E. R. \& Dias, A. (2021). Shelf life extension of peach palm heart packed in different plastic packages. Horticultura Brasileira, 39(1), 26-31. https://doi.org/10.1590/s0102-053620210104

Rojas-Garbanzo, C., Pérez, A. M., Pineda Castro, M. L. \& Vaillan, F. (2012). Major physicochemical and antioxidant changes during peach-palm (Bactris gasipaes H.B.K.) flour processing. Fruits, 67(6), 415-427. https://doi.org/10.1051/fruits/2012035

Sadaka, S. (2020). Reanalyze previous data to develop a universal kinetic model for grain sorghum drying process. In $2020 A S A B E$ Annual International Virtual Meeting (p. 1). American Society of Agricultural and Biological Engineers. https://doi.org/10.13031/ aim.202000218
Santacruz, S., Cárdenas, G. y Mero, V. (2020). Compuestos fenólicos y aceite de semillas de naranja y maracuyá. Revista de la Facultad de Agronomía de la Universidad del Zulia, 37(1), 51-68. https:// cutt.ly/fEgZ6bQ

Schroth, G., Elias, M. E. A., Macêdo, J. L., Mota, M. S. S. \& Lieberei, R. (2002). Mineral nutrition of peach palm (Bactris gasipaes) in Amazonian agroforestry and recommendations for foliar analysis. European Journal of Agronomy, 17(2), 81-92. https:// doi.org/10.1016/S1161-0301(01)00142-3

Sharma, G. P., Verma, R. C. \& Pathare, P. (2005). Mathematical Modeling of infrared radiation thin layer drying of onion slices. Journal of Food Engineering, 71(3), 282-286. https://doi. org/10.1016/j.jfoodeng.2005.02.010

Shi, J., Pan, Z., McHugh, T. H., Wood, D., Hirschberg, E. \& Olson, D. (2008). Drying and quality characteristics of fresh and sugarinfused blueberries dried with infrared radiation heating. $L W T$ Food Science and Technology, 41(10), 1962-1972. https://doi. org/10.1016/j.lwt.2008.01.003

Simal, S., Femenia, A., Garau, M. C. \& Rosselló, C. (2005). Use of exponential, Page's and diffusional models to simulate the drying kinetics of kiwi fruit. Journal of Food Engineering, 66: 323-328. https://doi.org/10.1016/j.jfoodeng.2004.03.025

Simpson, R., Ramírez, C., Nuñez, H., Jaques, A. \& Almonacid, S. (2017). Understanding the success of Page's model and related empirical equations in fitting experimental data of diffusion phenomena in food matrices. Trends in Food Science and Technology, 62: 194-201. https://doi.org/10.1016/j.tifs.2017.01.003

Sozzi, A., Zambon, M., Mazza, G. \& Salvatori, D. (2021). Fluidized bed drying of blackberry wastes: Drying kinetics, particle characterization and nutritional value of the obtained granular solids. Powder Technology, 385: 37-49. https://doi.org/10.1016/j. powtec.2021.02.058

StatSoft Inc. (2007). Statistica (Data Analysis Software System) version 8.0 www.statsoft.com. Palo Alto, California, USA.

Taghian-Dinani, S., Hamdami, N., Shahedi, M. \& Havet, M. (2014). Mathematical Modeling of hot air/electrohydrodynamic (EHD) drying kinetics of mushroom slices. Energy Conversion and Management, $86, \quad 70-80 . \quad$ https://doi.org/10.1016/j. enconman.2014.05.010

To-rul, H. (2006). Suitable drying model for infrared drying of carrot. Journal of Food Engineering, 77(3), 610-619. https://doi. org/10.1016/j.jfoodeng.2005.07.020

Togrul, I. T. \& Pehlivan, D. (2002). Mathematical modelling of solar drying of apricots in thin layers. Journal of Food Engineering, 55(3), 209-216. https://doi.org/10.1016/S0260-8774(02)00065-1

Velásquez, J. R., Roca-Argüelles, M., Rodríguez-Sánchez, J. L., Díaz, R., Hernández-Monzón, A. y Montiel, C. (2017). Caracterización de la harina de subproductos de palmito. Ciencia y Tecnología de Alimentos, 27(1), 24-28. https://cutt.ly/CEgJXN2

Vieira, T. F., Corrêa, R. C. G., Moreira, R. D. F. P. M., Peralta, R. A., de Lima, E. A., Helm, C. V., ... \& Peralta, R. M. (2021). Valorization of Peach Palm (Bactris gasipaes Kunth) Waste: Production of Antioxidant Xylooligosaccharides. Waste and Biomass Valorization, 1-14. https://doi.org/10.1007/s12649-021-01457-3

Waldron, K. W., Parker, M. L. \& Smith, A. C. (2003). Plant cell walls and food quality. Comprehensive Reviews in Food Science and Food Safety, 2(4), 128-146. https://doi.org/10.1111/j.1541-4337.2003. tb00019.x

Westerman, P. W., White, G. M. \& Ross, I. J. (1973). Relative humidity effect on the high temperature drying of shelled corn. Transactions of the American Society of Agricultural Engineers, 16: 1136-1139. https://doi.org/10.13031/2013.37715

White, G.M., Ross, I. J. \& Ponelert, R. (1981). Fully exposed drying of popcorn. Transactions of the American Society of Agricultural Engineers, 24:466-468. https://doi.org/10.13031/2013.34276

Yaldiz, O. \& Ertekin, C. (2001). Thin layer solar drying some different vegetables. Drying Technology, 19(3-4), 583-597. https://doi. org/10.1081/DRT-100103936

Zhang, Q. \& Litchfield, J. B. (1991). An optimization of intermittent corn drying in a laboratory scale thin layer dryer. Drying Technology, 9(2), 383-395. https://doi.org/10.1080/07373939108916672

Zhao, P., Ge, S., Ma, D., Areeprasert, C. \& Yoshikawa, K. (2014). Effect of hydrothermal pretreatment on convective drying characteristics of paper sludge. ACS Sustainable Chemistry \& Engineering, 2(4), 665-671. https://doi.org/10.1021/sc4003505 